\title{
THE STATISTICAL AND TECHNICAL EVALUATION OF THE WASTEWATER TREATMENT PLANTS IN HOLIDAY RESORTS
}

\author{
Aysegul Pala***, Ecem Kocabıyık*, Gunes Kursun ${ }^{* * *}$ \\ * Dokuz Eylül University, Faculty of Engineering, Department of Environmental Engineering, Izmir, Turkey \\ ** Dokuz Eylül University, Center for Environmental Research and Development, Izmir, Turkey \\ *** Dokuz Eylül University, The Graduate School of Natural and Applied Sciences, Izmir, Turkey \\ corresponding author: Aysegul Pala, e-mail: aysegul.pala@deu.edu.tr
}

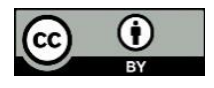

This work is licensed under a

Creative Commons Attribution 4.0

International License
Professional paper

Received: October $14^{\text {th }}, 2019$

Accepted: January $7^{\text {th }}, 2020$

HAE-1923

https://doi.org/10.33765/thate.10.3.3

\begin{abstract}
The aim of this study is technical and statistical evaluation of wastewater treatment plants existing at the holiday resorts in areas surrounding Izmir City. The study was carried out in the time period from August to September 2018. Within the scope of the study, 150 holiday resorts were investigated and listed. The necessary permissions were obtained and the treatment plants were visited at their current locations. Most of the wastewater treatment plants are embedded in the ground and are referred to as package treatment systems. They are used at holiday resorts for many reasons, such as smell and noise control. Many parameters have been considered within the scope of the study, such as installed power of the plant, influent wastewater flow and pollutant concentration, the properties of the sludge, sludge disposal methods, effluent wastewater parameters, the method and location of effluent water discharge, operation period of the wastewater treatment plant. As a result of this study, it has been found that the low cost package treatment systems were generally preferred. The systems that required most energy were the blowers. In order to provide clean and smooth environment, the use of central wastewater treatment plants is more suitable than the use of package treatment systems.
\end{abstract}

Keywords: holiday resorts, domestic wastewater, wastewater treatment plant, package treatment

\section{INTRODUCTION}

The water pollution problem is an important and increasing issue. That is why the rise of the environmental consciousness becomes more significant in national and international levels.
The existing water treatment and distribution systems are of great importance because of the water quality standards [1]. There are many different wastewater treatment processes, such as mechanical, biological, physical and chemical, which are usually used separately or together depending on discharge standards into receiving media or reclamation and reuse purposes. 
Wastewater is measured with parameters such as biological oxygen demand (BOD), chemical oxygen demand (COD), ammonium, orthophosphate, nitrate etc. These parameters provide significant impact on the quality of the influent, effluent wastewater [2].

In this study, the holiday resorts in areas surrounding the City of Izmir have been investigated to understand the recent wastewater treatment plants situation and their performances.

It is estimated that there are over 2000 small scale package plants for tourist settlements in Turkey [3]. In holiday resorts, package treatment systems are generally used for 100 to 1000 people and also for touristic places and seasonal activities.

Package treatment systems are designed for low flow rate domestic wastewater treatment with high organic pollution load. It is common in low populated settlements (summer sites, holiday resorts etc.). These systems are fully automatically designed and no operator is needed [4].

Wastewater treatment plants are generally placed on the ground or underground as package treatment systems for sewer infrastructure in tourist resorts. Consultant firms or site managers are responsible for accessing and entering the required information in the Turkish Integrated Environmental Information System (EÇBS) to be reported to the Provincial Department of Environment.

\section{EXPERIMENTAL}

Within the scope of this study, 150 facilities registered to (EÇBS) were investigated. The data obtained from EÇBS were evaluated with different parameters and summarized as follows. These parameters are given in Table 1.

\section{RESULTS AND DISCUSSION}

As a result of the 150 facilities investigated, $50.66 \%$ were in Küçük Menderes Basin, 1.33 $\%$ were in Gediz, $1.33 \%$ in Büyük Menderes Basin and $24 \%$ in North Aegean Basin. Küçük Menderes Basin, the area is about 702,931 ha, and accounts for $0.9 \%$ of the total Turkey's surface. According to 2012 Turkey statistical institute (TUIK) data, total population of municipalities in the basin is $3,237,054$ people. Within the borders of Küçük Menderes Basin, $56 \%$ of İzmir province, $16 \%$ of Aydin province and $0.8 \%$ of the province of Manisa are situated. The surface water potential constitutes approximately $0.29 \%$ of the country's territory. One of the most serious problems in water quality in streams of Küçük Menderes Basin are organic matter, nitrogen, colour, dissolved oxygen, and salinity values and it is in the category of highly polluted water [5].

Biological treatment methods are preferred for domestic wastewater treatment holiday resorts, in the light of the data obtained from the Provincial Directorate of Environment. It has been revealed that the treatment is carried out by using the activated sludge method. Package biological treatment is mostly used. According to the data obtained from the study, only 6 out of 150 facilities are not in operation.

The treatment plants, 89 out of 150 are exempt from project approval. Three facilities do not have project approval. Investment costs of plants are lower than $15,695 €$ generally and it shows also random range as shown in Figure 1. Four facilities out of 150 do not use effluent wastewater for irrigation purposes. They discharge it into the dry stream bed.

Different stabilization methods were used according to the amount of sludge and dry matter ratio and dewatering methods. $20 \%$ of the facilities use lime stabilization as a stabilization method, $12 \%$ use aerobic stabilization. The other part is controlled by IZSU (Izmir Water and Sewerage Administration) by transferring it with vacuum truck. 
Table 1. Parameters evaluated in this study

\begin{tabular}{|c|c|}
\hline Facility basin & $\begin{array}{l}\text { Basin is defined as a part of a land that contains all the natural resources } \\
\text { managed. All resources to ensure the integrity of the concept were also } \\
\text { identified as watershed management. The main basins of the facilities in İzmir } \\
\text { are Küçük Menderes, Gediz, and North Aegean Basins. }\end{array}$ \\
\hline Wastewate & $\begin{array}{l}\text { astewater is divided into industrial and domestic wastewater. Holiday resort } \\
\text { aters are domestic wastewaters. }\end{array}$ \\
\hline Treatment type & $\begin{array}{l}\text { Design parameters are obtained with analysis of wastewater in a laboratory. } \\
\text { According to the pollution determined by engineering studies, physical, } \\
\text { chemical, and biological types of treatment are clarified to design the treatment } \\
\text { plant. }\end{array}$ \\
\hline $\begin{array}{r}\text { Activ } \\
\operatorname{tr}\end{array}$ & $\begin{array}{l}\text { xistence of treatment facility in a region or holiday resorts does not indicate } \\
\text { activity. It should be controlled. }\end{array}$ \\
\hline Commissioning date & $\begin{array}{l}\text { Design of the wastewater treatment plants required permissions. It takes time } \\
\text { to start the construction of the system and to get the system up and running. } \\
\text { This required time is different in each project under the influence of many } \\
\text { variables. Important in this respect is the date on which the system starts } \\
\text { operating. }\end{array}$ \\
\hline $\begin{array}{r}\text { Constru } \\
\mathrm{d} c\end{array}$ & $\begin{array}{l}\text { he construction end date will affect the commissioning date and provides } \\
\text { formation about the rapid start of use. }\end{array}$ \\
\hline Project approval & $\begin{array}{l}\text { pproval of each facility is needed within the scope of the changing } \\
\text { ns. }\end{array}$ \\
\hline Cost of inve & $\begin{array}{l}\text { preferred system for wastewater treatment in holiday resorts are } \\
\text { treatment systems. One of the biggest factors in the choice is low } \\
\text { al cost as well as low initial investment cost. }\end{array}$ \\
\hline $\begin{array}{r}\text { Installed } \\
\text { the } \mathrm{f}\end{array}$ & apacity of the \\
\hline $\begin{array}{l}\text { Treatment plant } \\
\text { capacity }\end{array}$ & $\begin{array}{l}\text { amount of wastewater is directly proportional to the population, } \\
\text { acity of the treatment plant in holiday resorts limit to the capacity } \\
\text { plant. }\end{array}$ \\
\hline $\begin{array}{l}\text { Discharge point and } \\
\text { location }\end{array}$ & $\begin{array}{l}\text { y taking necessary permissions to the discharge points in accordance with the } \\
\text { gulations, discharge should be done by appropriate methods to the } \\
\text { ivironment considering human health. }\end{array}$ \\
\hline Total $\mathrm{w}$ & ure of capacity of wastewater treatment plant. \\
\hline $\begin{array}{l}\text { Inlet/outlet water } \\
\text { characteristics }\end{array}$ & $\begin{array}{l}\text { e biological oxygen demand (BOD), chemical oxygen demand (COD), total } \\
\text { spended solids (TSS) and } \mathrm{pH} \text { are the influent and effluent wastewater } \\
\text { aracteristics. }\end{array}$ \\
\hline Sludge formation & $\begin{array}{l}\text { nount of sludge, stabilization method, dry sludge percentage account for the } \\
\text { dge management. }\end{array}$ \\
\hline $\begin{array}{l}\text { Annual operating } \\
\text { cost }\end{array}$ & $\begin{array}{l}\text { lount of expenses, such as electricity needs and consultancy of } \\
\text { enses. }\end{array}$ \\
\hline $\begin{array}{l}\text { Energy consumption } \\
\text { amounts }\end{array}$ & Energy consumed in $\mathrm{kWh} /$ year is energy consumption. \\
\hline & $\begin{array}{l}\text { It is the yield of the discharge of incoming wastewater to the receiving } \\
\text { environment after treatment. }\end{array}$ \\
\hline Current $\mathrm{v}$ & It shows that water supply source for domestic usage. \\
\hline $\begin{array}{c}\text { Separate elect } \\
\text { clock }\end{array}$ & $\begin{array}{l}\text { Approximately } 10 \% \text { of wastewater treatment plants are connected to a } \\
\text { separate electricity clock. The remaining wastewater treatment plants take } \\
\text { electricity from the main power supply system in holiday resorts. }\end{array}$ \\
\hline
\end{tabular}




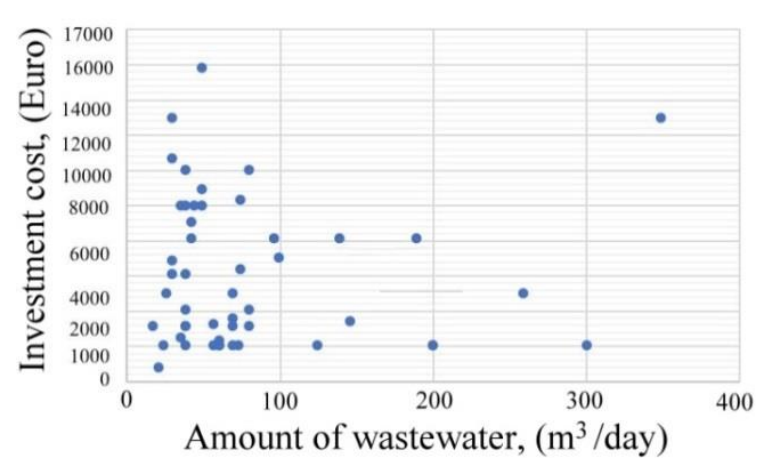

Figure 1. Investment costs versus wastewater flow

Frequency analysis of influent TSS is given in Table 2 and also frequency distribution is shown in Figure 2.

Table 2. Frequency analysis of influent TSS

\begin{tabular}{|c|c|c|c|c|}
\hline Class & $\begin{array}{c}\text { Class } \\
\text { range }\end{array}$ & $\begin{array}{c}\text { Sample } \\
\text { frequency } \\
(\mathrm{n})\end{array}$ & $\begin{array}{c}\text { Frequency } \\
(\mathrm{n} / \mathrm{N})\end{array}$ & $\begin{array}{c}\text { Cumulative } \\
\text { frequency }\end{array}$ \\
\hline 1 & $\begin{array}{c}36<\mathrm{X} \leq \\
276\end{array}$ & 86 & 0.57 & 0.57 \\
\hline 2 & $\begin{array}{c}276<\mathrm{X} \\
\leq 516\end{array}$ & 7 & 0.04 & 0.62 \\
\hline 3 & $\begin{array}{c}516<\mathrm{X} \\
\leq 756\end{array}$ & 55 & 0.37 & 0.98 \\
\hline 4 & $\begin{array}{c}756<\mathrm{X} \\
\leq 996\end{array}$ & 2 & 0.01 & $0,999 \approx 1$ \\
\hline
\end{tabular}

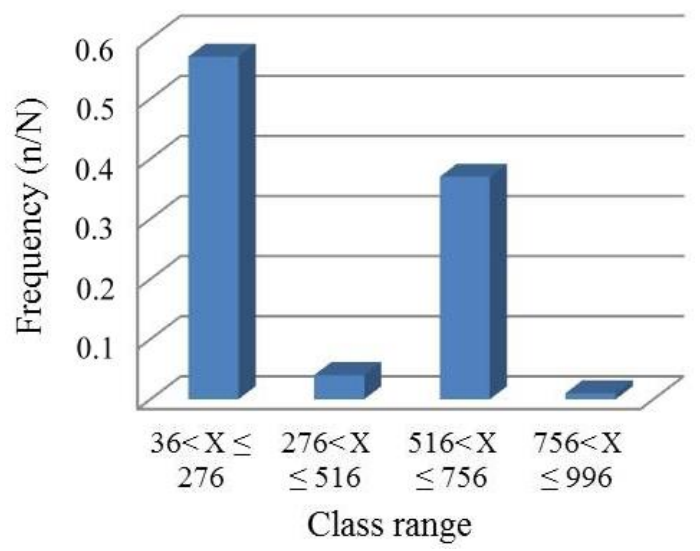

Figure 2. Distribution of TSS

It is noted that significant part of TSS variation $(57 \%)$ is in the range of $36-276 \mathrm{mg} / \mathrm{L}$. On the other hand, the resting part is between 516 and $756 \mathrm{mg} / \mathrm{L}$ with the percentage of $37 \%$.

Table 3 and Figure 3 show BOD variations in wastewater. It can be noted that influent BOD concentration is between 26 and $398 \mathrm{mg} / \mathrm{L}$ in $82 \%$ of the facilities.
Table 3. Frequency analysis of influent BOD

\begin{tabular}{|c|c|c|c|c|}
\hline Class & $\begin{array}{c}\text { Class } \\
\text { range }\end{array}$ & $\begin{array}{c}\text { Sample } \\
\text { frequency } \\
(\mathrm{n})\end{array}$ & $\begin{array}{c}\text { Frequency } \\
(\mathrm{n} / \mathrm{N})\end{array}$ & $\begin{array}{c}\text { Cumulative } \\
\text { frequency }\end{array}$ \\
\hline 1 & $\begin{array}{c}26<\mathrm{X} \leq \\
212\end{array}$ & 68 & 0.45 & 0.45 \\
\hline 2 & $\begin{array}{c}212<\mathrm{X} \leq \\
398\end{array}$ & 56 & 0.37 & 0.83 \\
\hline 3 & $\begin{array}{c}398<\mathrm{X} \leq \\
584\end{array}$ & 25 & 0.17 & 0.99 \\
\hline 4 & $\begin{array}{c}584<\mathrm{X} \leq \\
770\end{array}$ & 1 & 0.01 & $0.999 \approx 1$ \\
\hline
\end{tabular}

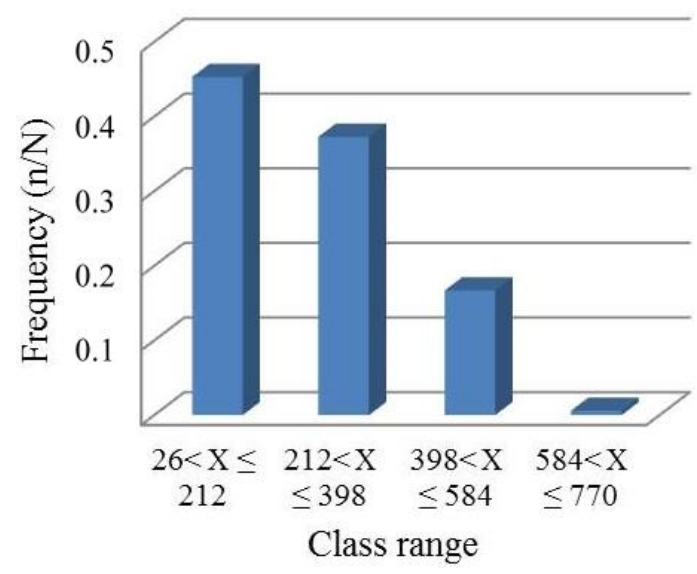

Figure 3. Distribution of BOD

Frequency analysis of influent COD is given in Table 4 and also frequency distribution is shown in Figure 4.

Table 4. Frequency analysis of influent COD

\begin{tabular}{|c|c|c|c|c|}
\hline Class & $\begin{array}{c}\text { Class } \\
\text { range }\end{array}$ & $\begin{array}{c}\text { Sample } \\
\text { frequency } \\
(\mathrm{n})\end{array}$ & $\begin{array}{c}\text { Frequency } \\
(\mathrm{n} / \mathrm{N})\end{array}$ & $\begin{array}{c}\text { Cumulative } \\
\text { frequency }\end{array}$ \\
\hline 1 & $\begin{array}{c}116<\mathrm{X} \leq \\
309\end{array}$ & 49 & 0.33 & 0.33 \\
\hline 2 & $\begin{array}{c}309<\mathrm{X} \leq \\
502\end{array}$ & 58 & 0.39 & 0.71 \\
\hline 3 & $\begin{array}{c}502<\mathrm{X} \leq \\
695\end{array}$ & 27 & 0.18 & 0.89 \\
\hline 4 & $\begin{array}{c}695<\mathrm{X} \leq \\
888\end{array}$ & 16 & 0.11 & $0.902 \approx 1$ \\
\hline
\end{tabular}

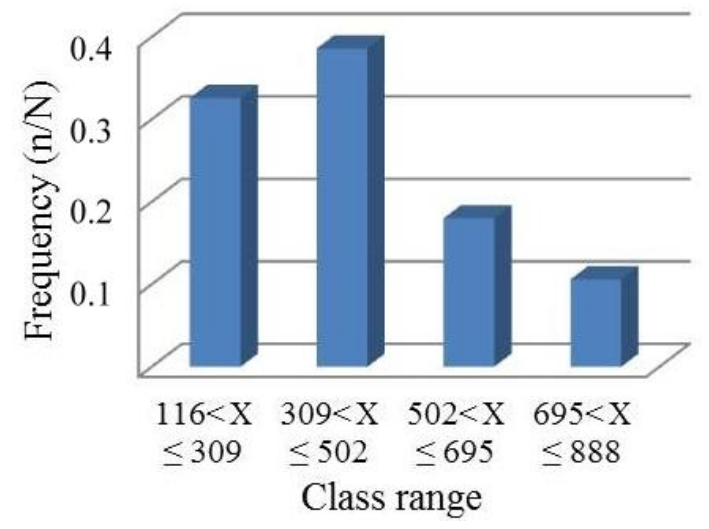

Figure 4. Distribution of COD 
When Table 4 is examined, it is evident that the COD values are in the range of $116-502$ $\mathrm{mg} / \mathrm{L}$ (Figure 4). The discharge standards of TSS, BOD and COD values for different wastewater treatment types in Turkey are shown on Table 5.

Table 5. Discharge standards in Turkey for different wastewater treatment types

\begin{tabular}{|c|c|c|c|c|c|}
\hline \multirow{2}{*}{ Parameter } & & \multicolumn{4}{|c|}{ Wastewater treatment type } \\
\cline { 3 - 6 } & Unit & $\begin{array}{c}\text { Raw } \\
\text { wastewater }\end{array}$ & $\begin{array}{c}\text { Classic } \\
\text { activated } \\
\text { sludge }\end{array}$ & $\begin{array}{c}\text { Membrane } \\
\text { bioreactor } \\
\text { (MBR) }\end{array}$ & $\begin{array}{c}\text { Activated } \\
\text { sludge }+ \\
\text { Microfiltration } \\
+ \text { Reverse } \\
\text { osmosis }\end{array}$ \\
\hline TSS & $\mathrm{mg} / \mathrm{L}$ & $120-400$ & $5-25$ & $<2$ & $<1$ \\
\hline BOD & $\mathrm{mg} / \mathrm{L}$ & $110-350$ & $5-25$ & $<1-5$ & $<1$ \\
\hline COD & $\mathrm{mg} / \mathrm{L}$ & $250-800$ & $40-80$ & $<10-30$ & $<2-10$ \\
\hline
\end{tabular}

Frequency analysis of influent $\mathrm{pH}$ values in wastewater is shown in Table 6 . The $\mathrm{pH}$ of domestic wastewater is expected to be between 6.87 and 8.46 (97\%). The frequency graph is shown in Figure 5.

Table 6. Frequency analysis of influent $\mathrm{pH}$ values in wastewater

\begin{tabular}{|c|c|c|c|c|}
\hline Class & Class range & $\begin{array}{c}\text { Sample } \\
\text { frequency } \\
(\mathrm{n})\end{array}$ & $\begin{array}{c}\text { Frequency } \\
(\mathrm{n} / \mathrm{N})\end{array}$ & $\begin{array}{c}\text { Cumulative } \\
\text { frequency }\end{array}$ \\
\hline 1 & $\begin{array}{c}6.87<\mathrm{X} \leq \\
7.4\end{array}$ & 41 & 0.27 & 0.27 \\
\hline 2 & $\begin{array}{c}7.4<\mathrm{X} \leq \\
7.93\end{array}$ & 74 & 0.49 & 0.77 \\
\hline 3 & $\begin{array}{c}7.93<\mathrm{X} \leq \\
8.46\end{array}$ & 32 & 0.21 & 0.98 \\
\hline 4 & $\begin{array}{c}8.46<\mathrm{X} \leq \\
9\end{array}$ & 3 & 0.02 & $0.999 \approx 1$ \\
\hline
\end{tabular}

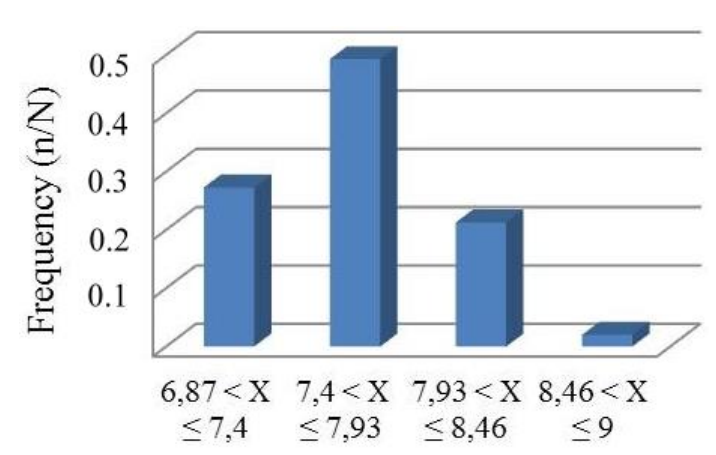

Class range

Figure 5. Distribution of $\mathrm{pH}$ values

Daily operating cost, such as personnel, chemicals, fuel and electricity costs, transportation cost, maintenance and repair costs, insurance cost, overhead cost is shown in Figure 6. It can be said that it is stable from 25 to $350 \mathrm{~m}^{3} /$ day wastewater treatment capacity.

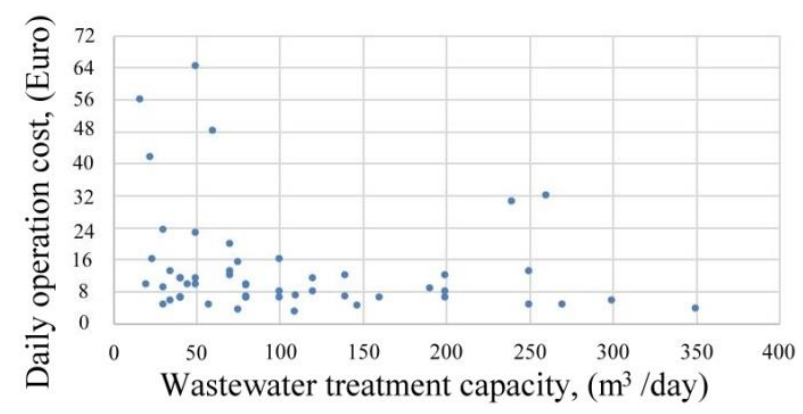

Figure 6. Daily operating costs and wastewater treatment capacities of facilities

Installed capacity of wastewater treatment plants is shown on Figure 7. As it is seen, there are some data very far from the operation with energy efficient use of the treatment plants.

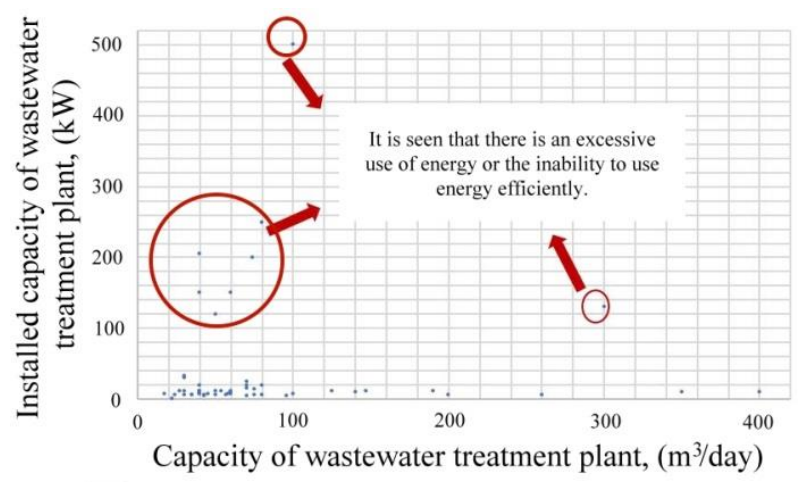

Figure 7. Impact of treatment plant capacity on installed capacity of the plant

\section{CONCLUSION}

In this study, 150 holiday resorts from Izmir region have been investigated. The data were obtained through Ministry of Environment and Urbanization of Turkey Integrated System (EÇBS). The results of the study are summarized below:

- Package underground wastewater plants systems generally are used at holiday resorts for noise and smell control. 
- The wastewater treatment plant type is generally extended aeration activated sludge system. MBR (Membrane Bioreactor) system can be suggested to use the effluent wastewater for irrigation purposes to comply with the irrigation water quality requirements, and RBD (Rotating bio-disc) can be suggested to reduce the operational cost of treatment plants.

- The most energy-consuming part in package treatment are the blowers. Failure to perform regular maintenance and inspections increases energy consumption. The old ones should be replaced with new, more environmentally friendly equipment. The least energy consuming systems should be preferred. RBD (Rotating bio-disc) technology is a good example of this.

- In addition to revision and system change, the other solution to the energy problem is the use and promotion of renewable energy. All of the resorts that were examined within the scope of the project are located in the temperate warm climate zone which receives sunshine almost any time of year. It would be a good choice to meet the energy requirements of both domestic usage and wastewater treatment plants with solar energy panels.

- There is no significant relationship between investment cost and the flow of influent domestic wastewater. It depends on the companies' offer.

- The usage of electricity is variable even in the treatment plants of the same size, and it shows that some of them cannot use the energy efficiently.

\section{REFERENCES}

[1] Q. Xiaolei, P.J.J. Alvarez, Q. Li, Applications of nanotechnology in water and wastewater treatment, Water Research 47(2013) 12, 3931-3946. https://doi.org/10.1016/j.watres.2012.09. $\underline{058}$

[2] Y. Zhou, J. Meng, M. Zhang, S. Chen, B. He, H. Zhao, Q. Li, S. Zhang, T. Wang, Which type of pollutants need to be controlled with priority in wastewater treatment plants: Traditional or emerging pollutants?, Environment International 131(2019), 104982.

https://doi.org/10.1016/j.envint.2019.104 $\underline{982}$

[3] B. Maryam, H. Büyükgüngör, Wastewater reclamation and reuse trends in Turkey: Opportunities and challenges, Journal of Water Process Engineering 30(2019), 100501, https://doi.org/10.1016/j.jwpe.2017.10.0 $\underline{01}$

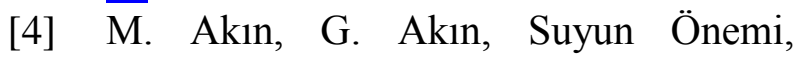
Türkiye'de Su Potansiyeli, Su Havzalari Ve Su Kirliliği, Ankara Üniversitesi Dil ve Tarih-Coğrafya Fakültesi Dergisi 47(2007) 2, 105-118.

[5] http://www.protecharitim.com, Accessed: April 3, 2019. 